\title{
The Paradox of Being a Wounded Healer: Henri J.M. Nounen's Contribution to Pastoral Theology
}

\begin{abstract}
Authors:
S. Philip Nolte ${ }^{1}$

Yolanda Dreyer
\end{abstract}

\section{Affiliations:}

${ }^{1}$ Department of Practical Theology, University of Pretoria, South Africa

\section{Correspondence to:} Philip Nolte

email:

philip.nolte@iburst.co.za

\section{Postal address:}

Department of Practical Theology, Faculty of Theology, University of Pretoria, Lynnwood Road, Hatfield 0083, Pretoria, South Africa

\section{Keywords:}

Pastoral care; Henri J.M. Nouwen; wounded healer; Carl Jung and mythological origins; cognitive dissonance

Dates:

Received: 30 Apr. 2010

Accepted: 19 Aug. 2010

Published: 11 Nov. 2010

How to cite this article Nolte, S.P. \& Dreyer, Y., 2010, 'The Paradox of Being a Wounded Healer: Henri J.M. Nouwen's Contribution to Pastoral Theology', HTS Teologiese Studies/Theological Studies 66(2), Art. \#861, 8 pages. DOI: 10.4102/hts.v66i2.861

\section{This article is available} at: http://www.hts.org.za

Note:

This article is an abridged version of a chapter from Dr. S. Philip Nolte's PhD dissertation, entitled 'Pastors as gewonde genesers: Emosionele intelligensie en pastoraat (Pastors as wounded healers: emotional intelligence and pastoral care)'. The dissertation was completed in 2007 under the supervision of Prof. Dr Yolanda Dreyer, Professor in the Department of Practical Theology of the Faculty of Theology, University of Pretoria, and was accepted by the University of Pretoria.

\section{ABSTRACT}

This article is the first in a series of two dealing with Henri Nouwen's contribution to pastoral care. The present article focuses on the impact of cognitive dissonance and the role it plays in pastors becoming constrained in their ministry. The point of departure is that during the past two decades, pastors have been subjected to profound changes. While pastors view their involvement with people in the social and faith communities in which they live and work as guiding people towards a life of wholeness and integrity, they themselves, because of their own inner woundedness, struggle to live a life of wholeness. This article investigates how pastors can act congruently and with integrity in a world that has been profoundly changed by a shift from a modern to a postmodern paradigm. This reflection explores the ancient Greek mythological origins of the concept 'wounded healer'. It also shows that, in its utilisation by the Swiss psychiatrist Carl Jung, the concept became a metaphor. This insight leads to a discussion of how Henri Nouwen applied the significance of the metaphor to pastoral ministry. The discussion takes on the form of certain relevant biographical side notes on Nouwen's contribution to pastoral theology. The article concludes with an exposition of Nouwens's use of the metaphor in his book, The wounded healer: Ministry in contemporary society.

\section{INTRODUCTION}

\section{Pastors and inner woundedness}

The reason for pastor's engagement with people is to guide them in such a way and to such an extent that it will bring about a transformation leading to a life of wholeness and integrity for both pastors and the people they minister to. Those who are guided, all suffer from inner wounds, for example:

- people who are physically and emotionally abused

- rape victims

- people living with HIV / Aids

- $\quad$ people who lose their jobs

- people suffering from terminal illnesses.

The process of guiding people to deal and cope with their woundedness in a meaningful way requires wisdom and understanding, as well as emotional energy from the pastor. Because of pastors' very own humanness, they too experience inner woundedness. This woundedness can be described as a loss of integrity, by which is meant that because of their own woundedness, pastors themselves struggle to live as whole persons. This woundedness leads to a feeling of disempowerment, which manifests as a lack of emotional energy in relation to their ministry.

Sometimes pastors may have a vague notion that their woundedness originates from a certain tension between their ministry - which includes their theological reflection - and their humanity. Gerben Heitink ([1977] 1984:16) states that a distinction needs to be made between a Pastors' personal identity and their pastoral identity. Heitink is also of the opinion that the interwovenness of personal existence and occupation is nowhere as complex as it is in the case of pastors. There exists a close relationship between a pastor's inner life and their everyday ministry, which means that a pastor's emotions and emotional woundedness play a significant role in their ministry. The purpose of pastoral interaction between pastors and people they minister to is healing and wholeness - in other words, a process through which people may experience healing on a psychological and spiritual level and may grow in terms of their humanity, their faith and in their service to others.

Pastors' woundedness may lead to inner conflict in terms of the way in which they view and experience themselves, which in turn, may have a negative influence on their humanness and their ministry. For example, pastors may question church doctrine while realising that they are not allowed to discuss their views openly in their congregations or with colleagues. Because of this inner conflict pastors experience emotions such as frustration, uncertainty and anger. This leads to further internal conflict when pastors do not have a forum where they can discuss their emotional experiences as well. When their emotions are repressed, pastors may suffer from depression and other health problems in the long run. The emotional effect is a loss of energy and motivation which in turn leads to a decrease in productivity which in its turn leads to further personal conflict. Although pastors may experience their emotional woundedness negatively, and may lack the ability to deal with it in a meaningful way, paradoxically, their woundedness can serve as a source of healing in their personal lives, as well as in their relations with others. In his book, The wounded storyteller: Body, illness, and ethics, Arthur W. Frank (1995) reflects on the power of the narratives of people living with illness:

The ill, and all those who suffer, can also be healers. Their injuries become the source of the potency of their stories. Through their stories, the ill create empathic bonds between themselves and their listeners.

(Frank 1995:xii) 
Frank's view correlates with Henri J.M. Nouwen's insights on the metaphor of the wounded healer: 'Because stories can heal, the wounded healer and wounded storyteller are not separate, but are different aspects of the same figure' (1995:xii, my emphasis). The problem, however, is that pastors often struggle to integrate this view into their lives. In South Africa one of the reasons for this struggle lies in a profound tension between present realities and a specific view on theological and religious matters.

\section{Cognitive dissonance}

The reason why pastors experience inner woundedness is related to a paradigm shift, particulary the shift from a modern paradigm to a postmodern one. Postmodernity is characterised by, among others, the relativisation of many ideas that used to be regarded as definite and certain. This includes the relativisation of religious and Biblical 'truths' and because of the complexity and multidimensionality of the questions, problems and challenges pastors have to deal with, the relativisation of biblical and religious truths leads to uncertainty and ambivalence. This ambivalence, in turn, is deepened by the dynamics of many religious changes which have occurred at the macrolevel of society, the mesolevel of the church, and at the microlevel of individuals (see Malherbe \& Louw 2002:516). The emotional struggle (i.e. feelings of disempowerment) that pastors experience as a result of the shift from a modern to a postmodern paradigm can be described as cognitive dissonance. Cognitive dissonance has to do with the fact that knowledge seems to be at odds with the realities people have to deal with on a daily basis. For example, a smoker could have all the knowledge about the medical risks of smoking, yet they may experience great difficulty in breaking free from nicotine addiction. In a Christian context cognitive dissonance occurs when Christians experience a conflict between what they accept as so-called 'objective knowledge' about values (in the Bible and church tradition) and the reality they live in. This phenomenon can be extremely complex, because people find themselves in a continuous communicative interaction with other people living in the same social context. This interaction becomes meaningful when people's knowledge about one another is grounded in a dynamic that creates shared feelings or dissociation and alienation.

M.A.K. Halliday (1978) argues that knowledge of others and of oneself functions on three levels: knowledge of 'who/what/ where/when'; knowledge of 'how to'; knowledge of 'which' (see also Malina 2001:7-19). Interpersonal relations are established because of communication that reveals how people feel, think and act. Dialogical interaction becomes distorted when people do not know how to act in the light of the knowledge that constitutes the source of their presuppositions, prejudices, expectations and evaluations about everydayness and existential experiences.

Cognitive dissonance is the result of feelings, thoughts and actions which are out of place and are therefore not congruent with what people know. Pastors experience cognitive dissonance because they find themselves and those with whom they interact in the same context (postmodern culture), but this context is interpreted from different paradigms. This can be illustrated by the way the Bible, as well as church tradition and doctrine are viewed and utilised.

In the Protestant tradition, the use of the Bible is not only viewed as important but as central to what one should know. The Protestant theological tradition, together with the important status assigned to church doctrines and creeds, determine the way in which pastors interpret the Bible and the way in which they use it in theological discourses. Many pastors still argue from a modern paradigm according to which the Bible and theological tradition offer adequate answers for contemporary problems. However, those pastors and their congregational audiences live in a postmodern culture. In this culture, the view that the Bible and church doctrines serve as the standard for people's relationship with God, as well as for their faith and lifestyle, is challenged and problematised at various levels. Many church members think about reality from within a postmodern paradigm, but their pastors and the faith communities they belong to are still upholding the modern paradigm.

In his book, The heart of Christianity: Rediscovering a life of faith, Marcus Borg (2003) describes the shift from modernity to postmodernity in the Christian faith tradition by distinguishing between an earlier (traditional) paradigm and an emerging paradigm. David Tracy (1981:104-114) describes postmodernity as a transformation from institutional religion, which is a result of modernity, to postmodern spiritualities. The shift from modernity to postmodernity can also be described as a kairos moment for Christian theology (see Hodgson 1994). A paradigm is 'a large interpretive framework that shapes how everything is seen, a way of constellating particulars into a whole' (Borg 2003:4).

It is this author's contention that Nouwen too struggled in his life with the question of how pastors could live and minister in an authentic way within a postmodern culture that is continuously evolving. The result of his struggle with this question was the development of the metaphor of the wounded healer.

This article presents a discussion of the origins of this metaphor as well as the way in which the Swiss psychiatrist Carl J. Jung utilised the metaphor in his writings. Nouwen is contextualised within a broader framework by way of biographical side-notes. Subsequently, Nouwen's contribution is appreciated against the background of a broader pastoral theological context, in order to reflect on the significance of his views on the metaphorical concept of the wounded healer. Preliminary findings will be presented and will serve as a transition to a subsequent article on Nouwen's spirituality and insights.

\section{INTRODUCTORY NOTES ON THE 'WOUNDED HEALER'}

\section{Greek origins}

Carl Jung ([1929] 1981:116) used the metaphor of the wounded healer to describe an aspect of a therapist's relationship with their patients. He ascribed his use of the metaphor to the Greek myth of Asclepius. According to two versions of this myth (Groesbeck 1975:124-127), Asclepius was the child of the Greek god, Apollo, and an earthly mother, Coronis. In one of these versions Asclepius was taken to mount Titthion by his mother directly after his birth. Mount Titthion was famous for its medicinal plants. There a voice from heaven announced that Asclepius would be able to heal all people and to raise people from the dead. In this version of the myth, Asclepius combined the creative characteristics belonging to his father, Apollo, with a rational side typified by medicine and healing (Groesbeck 1975:124).

According to another version of this myth, Coronis had an extra-marital affair with Ischus while pregnant with Asclepius. Enraged, Apollo sent his sister Artemis to kill Coronis. Artemis burnt Coronis on a funeral pyre. Meanwhile, as he was watching this scene, Apollo felt guilty of killing his unborn child and saved baby Asclepius by performing a caesarean section. After his ordeal, Asclepius was placed in the care of Chiron, a Centaur (a mythological figure with the body of a horse and the head of a human being). Although Chiron was famous for his healing powers, he was suffering from a wound that never healed. Chiron embodies a paradoxical irony: although he was a godlike figure, he could not heal himself. This paradox is also intriguing from the perspective that although Centaurs were known for their destructive powers, Chiron instructed people in the arts of healing and music (Groesbeck 1975:125). While in the care of Chiron, Asclepius developed the rationality associated with healing as well as qualities that respresent light; Asclepius inherited these qualities from his father. However, Asclepius also developed qualities of his teacher and surrogate father, Chiron, qualities that represent a dark or irrational side. Kerényi (1959, quoted by Groesbeck 1975) formulates the contradiction 
Chiron, the mythological wounded healer, represents as follows:

The picture to which all these elements, religious and poetic, give rise is unique. The half-human, half-theriomorphic god suffers eternally from his wound; he carries it with him to the underworld as though the primordial science that this mythological physician, precursor of the luminous divine physician, embodied for men of later times, were nothing other than the knowledge of a wound in which the healer forever partakes.

(Kerényi 1959:98-99, quoted by Groesbeck 1975:125)

The paradoxical mystery of the myth lies in the fact that the healer, who is able to heal all other wounds and illnesses, is not able to heal himself. The underlying view in the myth is that the healer is fully aware of the wound that never heals. Groesbeck (1975) purports that two important issues flow from this awareness, namely:

Why does the healer have to have knowledge (awareness) of his own wound; why does he need to share it again and again to effect the cure? Does this have a relationship to knowledge of, and participation in, the wounds of the patient? (Diagnosis and therapy?) Secondly, the myth of Asclepius is reflected in our day in the doctor-patient relationship as an archetypal aspect of the transference.

(Groesbeck 1975:125)

Nouwen is a living reminder of a theologian/pastor who lived with this paradox as a person who was able to help others experience processes of healing, but had to live with his own woundedness without being able to heal himself.

\section{Wounded pastors facilitate healing}

It is important to realise that there is a relationship between an external healer's therapy and the internal or intra-psychic healer of the wounded person. Healing takes place when the inner healer is activated and working together with the external healer in the healing process. In this process a relationship is created between doctor and patient, a relationship in which the phenomenon of transference/countertransference is activated, and forms part of a deep, unconscious psychological process. Groesbeck (1975) formulates this phenomenon as follows:

Because of his illness, the patient activates his 'inner physician or healer'. This, however, is not integrated into consciousness, but is projected onto and constellated by the persona of the doctor. So, too, in the doctor, his inner wounded side, his own unresolved illnesses, psychic, somatic or both are activated by his contact with the sick person. This opposite side of the archetypal image is projected onto the patient, rather than being contained within himself.

If the relationship remains like this, no movement to a real cure occurs, though remedies, physical and psychological, are applied. Real cure can only take place if the patient gets in touch with and receives help from his 'inner healer'. And this can only happen if projections of the healer's persona are withdrawn. This presupposes that the physician-healer is in touch with his own wounded side. If the projection remains, both doctor and patient attempt, .... to 'heal the split through power'. Each attempts to manipulate the other to conform to stereotyped roles.

(Groesbeck 1975:125, my emphasis)

Jung ([1954] 1969) describes this process in his work on transference/countertransference and demonstrates the paradoxical nature of this interaction, namely that it is a healer's wound that facilitates healing. Jung used the metaphor of the wounded healer to reflect on the relationship between therapist and patient. In his autobiography, Memories, Dreams, Reflections Jung ([1961] 1963) says ${ }^{1}$ :

The doctor is effective only when he himself is affected. Only the 'wounded physician' heals. But when the doctor wears his personality like a coat of armour, he has no effect.

(Jung [1961] 1963:134, my emphasis)

1.The significance of Jung's view on the metaphor of the wounded healer will be discussed in a separate article.
Jung's discussion of this issue shows that he regards the relationship between patient and therapist as one between equals, and not as one in which the therapist functions from a higher, clinical, objective position. Therapists have to recognise their own woundedness and consider what role it plays in therapeutical processes.

This insight is of particular significance for pastors and their ministry, because pastors find themselves in a similar relationship with the people they minister to. Both parties enter into a relationship with the totality of their being which comprises both the conscious and unconscious contents of their personality. Pastors have to realise that every relationship with another person is influenced by their own woundedness. As caregivers, they have the responsibility to be aware of this process and should utilise it to benefit their relationships with others. It is important for pastors to take their woundedness seriously and to consider how it influences specific situations.

When pastors and those to whom they minister deny their own woundedness, the danger of powerplay and manipulation enters into their relationships. Pastors can become so caught up in the denial of their own emotional woundedness that they, in their interactions with others, start to act in dogmatic and authoritarian ways. It is in such situations that pastors tend to use the Bible in a fundamentalist way as 'Word of God' and as 'objective rules for life' without taking people's life stories seriously. It is precisely in such situations that these pastors pretend to know what 'the best solutions' are for other people's 'problems', and present those as 'God's will'. This is a continuation of a positivistic epistemology in terms of which the end result (already decided upon by the pastor) is manipulated through the use of certain methods. The consequence is that people's life stories are not taken seriously, and only the information that reinforces the pastor's 'diagnoses' and 'prescriptions' is selected.

Such a disposition is underscored by a theory that so-called 'objective truth' is possible; in this instance, the 'objective truth' is about the correct solutions for people's problems. However, the consequence is that people who come to pastors with their life struggles are not assisted in gaining insight into their own inner psychological and religious processes. From a viewpoint of authentic, compassionate pastoral care, it is important to realise that:

- a positivistic attitude does not facilitate a process through which people's woundedness can be brought into the sphere of their own awareness

- therefore, people are not guided towards a safe space where they can discover that intense experience of their woundedness is a sign of emotional energy and that their emotional pain can, paradoxically, be utilised as a source towards healing.

I am of the opinion that Henri Nouwen can be viewed as a wounded healer who has emotional intelligence, because he was able to integrate the two dimensions of authentic, compassionate pastoral care mentioned above into his interaction with people.

\section{BIOGRAPHICAL SIDE-NOTES}

It is apt to refer to side-notes of Nouwen's life as brush strokes of a life because Nouwen so greatly admired the Dutch Impressionist painter, Vincent van Gogh. Nouwen (1989) articulates his identification with Van Gogh's life and work as follows:

I experienced connections between Vincent's struggle and my own, and realised more and more that Vincent was becoming my wounded healer. He painted what I had not before dared to look at; he questioned what I had not before dared to speak about; and he entered into the spaces of my heart that I dared not to come close to.

(Nouwen 1989:x)

Such was Nouwen's (1989:ix) admiration for Van Gogh, that during his time as teacher at the Yale Divinity School, he even offered a course in spirituality called 'The ministry of Vincent 
van Gogh'. Interestingly, Van Gogh's father was a Protestant pastor and Van Gogh had attended theological school and had a brief career as a missionary to a poor coal-mining community in a remote part of Belgium (Edwards 1989; Fell [2004] 2005:3) Van Gogh was a deeply spiritual person throughout his life and Nouwen saw him in a

similar focus and meditative spirit, a sincere yearning and true insight into God's presence in the world. God was in the fields, in the alleyways, in the glance of an old seaman or the tilted bonnet of a faded beauty.

(O'Laughlin 2005:83, see also Lévéque 1998:32; Edwards 1989; Fell [2004] 2005:2-4)

Nouwen's experience of emotional woundedness can be traced back to his childhood. Michael O'Laughlin (2005:19-20), in his biography of Nouwen, argues that from a very early age Nouwen experienced a profound sense of uncertainty and shame. Nouwen's father was an independent and career oriented person, constantly urging his sons to be independent and successful in their own right. Because of his father's particular attitude towards life, Nouwen found it difficult to experience his father as someone who loved him unconditionally. His mother, on the other hand, had a more gentle approach to life and constantly reminded Henri to stay close to God. O'Laughlin (2005) describes the consequence of these conflicting influences in Nouwen's life as follows:

In Henri's estimation, the voices of his parents were hard to reconcile. Which one was right? Probably the dichotomy was not as clear as it later seemed to Henri, but this point would trouble Henri for much of his lifetime.

(O'Laughlin 2005:15)

From Nouwen's books it becomes clear that the struggle to come to terms with his own woundedness and the deep-seated longing to be accepted unconditionally by others, and by God, form the main themes in his life and theological reflection.

Dealing with the memory of his need to be re-assured of his parent's love, Nouwen ([1992] 1994) writes as follows:

When I was a small child I kept asking my father and my mother: 'Do you love me?' I asked that question so often and so persistently that it became a source of irritation to my parents. Even though they assured me hundreds of times that they loved me I never seemed fully satisfied with their answers and kept asking the same question.

(Nouwen [1992] 1994:77-78)

This quest for unconditional love is poignantly articulated in Nouwen's book about Rembrandt's painting of the homecoming scene from the parable of the prodigal son (Nouwen [1992] 1994).

Nouwen was a brilliant scholar, speaker and author. He started his teaching career in the department of clinical psychology at the University of Notre Dame in the United States of America. However, he gradually realised that his main interest lay with theology and he later became a lecturer in the department of practical theology. His time in the United States coincided with the civil rights movement and he took an active part in the black community's struggle to break free from their second class citizenship. During this period, his personal/particular style of writing and speaking began to develop, one which eloquently expressed his insights into those questions that interested him most, namely spiritual and philosophical questions about intimacy, personal confusion and identity $\left(\mathrm{O}^{\prime}\right.$ Laughlin 2005:56-57)

From 1971 to 1981 Nouwen taught and ministered at the Yale Divinity School where he was a very popular lecturer and friend to many students. He was one of the first Roman Catholics to join the Protestant faculty of this famous academic institution (O'Laughlin 2005:64). In 1981 Nouwen resigned from his position at Yale and a few months later he travelled to Peru and Bolivia in Latin America. Although he only spent six months there, it was a time of profound personal transformation. What he had experienced during this time so influenced his thinking and vision that the brief time spent at the Harvard Divinity School after his travels ended in depression and his permanent departure from the academic world. Nouwen (1988) describes his time at Harvard as follows:

My decision to leave Harvard was a difficult one. ... Finally, I realised that my increasing inner darkness, my feeling of being rejected by some of my students, colleagues, friends, and even God, my inordinate need for affirmation and affection, and my deep sense of not belonging were clear signs that I was not following the way of God's spirit.

(Nouwen 1988:22)

These words give one an idea why Nouwen felt a deep affinity for Van Gogh, which can be partly ascribed to a similarity in temperament. Both were highly complex and unique individuals, especially in the way they perceived themselves and the world they lived in; both were very sensitive and creative persons (O'Laughlin 2005:84). Nouwen suffered from a deep sense of shame and frequently found himself on an emotional roller coaster, moving from equilibrium to joy to anxiety and to the verge of a nervous breakdown. The origins of Nouwen's sense of shame are not always clear, but one factor aggravating his condition was the fact that he was homosexual. In the Dutch Community, as well as in Roman Catholicism, homosexuality was regarded as abnormal, a mental illness and a sin. Homosexuality was never discussed in Nouwen's home. It was because of this particular view on (homo)sexuality that Nouwen believed something was wrong with him and that it had to be kept secret. Ironically, it was partly owing to his homosexuality that, as a writer, Nouwen evolved towards an attitude of increasing vulnerability and openness. Nouwen's honesty and transparency in terms of his struggles, doubts, fears and anxieties made him a sought-after writer and speaker. It is regrettable that he never developed the self-confidence to openly acknowledge his sexual orientation; he thought people would label him as 'gay priest' and that it would not be conducive to anything he would say and write about God, Jesus and spirituality from that point onwards.

The emotional and spiritual turmoil Nouwen experienced, guided him into becoming more trusting and open to God; it was the acknowledgement of his weaknesses and his own struggles that helped his readers to accept his counsel with gratitude, because they were able to identify with him as person. In view of the fact that our emotional experiences play such an important role in developing our sense of identity and how we experience God, I deem the following words of Nouwen (1976) as an important window that offers insight into his personality:

What do you do when you are always comparing yourself with other people? What do you do when you always feel that the people you talk to, hear of, or read about are more intelligent, more skillful, more attractive, more gentle, more generous, more practical, or more contemplative than you are? What do you do when you can't get away from measuring yourself against others, always feeling that they are the real people while you are a nobody or even less than that? ... I talked about this with John Eudes today. ... We talked about the vicious cycle one enters when one has a low self-esteem or self-doubt and then perceives other people in such a way as to strengthen and confirm these feelings. It is the famous self-fulfilling prophesy all over again. I enter into relationships with some apprehension and fear and behave in such a way that whatever the others say or do, I experience them as stronger, better, more valuable persons, and myself as weaker, worse, and not worth talking to. After a while the relationship becomes intolerable.

(Nouwen 1976:90-92)

I am convinced that it is this honesty about his inner turmoil that made Nouwen's life and message(s) the gift to the world it had become. His writings on pastoral and spiritual issues have been read by a wide variety of people and are increasingly appreciated as being of great value in academic, pastoral and theological circles. 


\section{NOUWEN IN AN ACADEMIC (PASTORAL THEOLOGICAL) CONTEXT}

Henri Nouwen explored the meaning of the 'wounded healer' metaphor in terms of practical theology and pastoral care. I consider Nouwen as an exemplar of 'practical theology as a way of life', to use Terry Veling's words. Veling (2005) formulates his conviction relating to practical theology as follows:

To imitate Christ is to follow Christ, and it is in following this way that we are led into the truth and life (John 14:6). This, in a nutshell, is the method of theology, the 'theological method.' And this is what it means to speak of practical theology as a way of life.

(Velling 2005:240, my emphasis)

Theology is not only rational theorising about God, life, our common humanity, creation or death. Nor is theology an individualistic preoccupation with questions about'salvation from personal sin and certainty about life after death' without social and political awareness and focus. In this context, the term 'political' does not refer to the narrow sense of the word pertaining to party politics, but is meant in a broader sense, that of the structuring of the polis, or community. In this sense, practical theology and pastoral care entail a political focus. The recent discourses about gender and homosexuality in South African faith communities serve as an example of such political and social focus. These discourses not only comprise different theories but address the important practical question of how Christian faith communities can assist people from different genders and with different sexual orientations to respect one another and live together in love and peace. Faith communities, wherein gay people are accepted for who they are and where they are integrated and understood, can become signs of hope, transformation and healing. Veling (2005:236-237) reflects on the idea of 'lived theology' by making use of the Greek noun methodos, which is a combination of meta and hodos, which can be translated as: 'a following after: a scientific enquiry or treatise: method, system' (Liddell \& Scott 1974:430).

Theology has to occupy itself on a continuous basis with the question of what it means to live authentically before God. In this process, theory and practice are closely related. Practical theology as 'practical application' of or 'supplement' to the 'more important theoretical considerations' of the Biblical sciences, is an artificial separation and not valid on epistemological grounds. Pierre Hadot (2002:176) argues that ancient philosophers were not only interested in knowledge for the sake of knowledge, but 'always intended to produce an effect, to create a habitus within the soul, or to provoke a transformation of the self'. In this sense, practical reason has precedence over theoretical reason. This vision of transformation of life as imitation of Christ played an important role in Nouwen's life and in this context it is prudent to take cognisance of the following formulation by Hadot (2002:238): 'The real problem is therefore not the problem of knowing this or that, but of being in this or that way'. It will be shown that in Nouwen's reflection on what it means for pastors to live as wounded healers, the concept of 'being' as a way of life is very important to Nouwen.

Practical theologians are increasingly recognising the value of Nouwen's contribution to practical theology (Capps 1980, 1984; Campbell [1981] 1986; Heitink 1997:558-581, [1998] 2000:85; Van der Ven 1998; Louw [1999] 2003). Even theologians from other disciplines integrate Nouwen's theological insights in their research (see Borg 2003:97, 100 n21). The value of Nouwen's contribution particularly lies in his discussions of the boundaries between psychology and pastoral care, as well as his views on the relation between pastoral care and spirituality (Heitink 2000:85; cf. Gillespie 2002:113). Spirituality can be described as an individual's religious experience and according to Heitink (1993:35), pastoral care is a process in which pastoral caregivers and those who seek care together are looking for ways in which they can experience the presence of God in their lives. In his discussion, Nouwen ([1969] 2000:231-279) shows that theology and psychology can function together at an interdisciplinary level, but for theology to maintain authenticity it has to transcend the boundaries of psychology. Authenticity is understood here as a life of wholeness before the face of God. Theological reflection is vital to such an understanding of an authentic life. Authenticity in pastors' lives means that their lives should be a living reminder of Jesus and they should be present in the lives of others in a healing way. Healing means to become 'whole' (Hiltner [1954] 1958:89), although this does not imply that pain would be removed from people's lives. Insights gained from psychology into the dynamic intrapsychological processes in people's lives can assist pastors to be present in other's lives in such a way that they can serve as a living reminder of Jesus (Nouwen [1969] 2000:246-250).

In 2005 a volume of essays, Images of pastoral care: Classic readings was published with Robert C. Dykstra, professor in pastoral theology at the Princeton Theological seminary, as editor. The essays cover the different metaphors in pastoral care and are written by various pastoral theologians who are regarded as pioneers in the field of pastoral care and pastoral theology, including Anton T. Boisen, Charles V. Gerkin and Seward Hiltner.

Dykstra (2005:69-149) included Nouwen's reflections on the wounded healer metaphor in the second section of this volume, which he called 'Paradoxical images of care'. Dykstra (2005) formulates pastor's experience of a paradoxical existence as follows:

The authors in this section employ paradox and paradoxical imagery to address the perils and predicaments of pastoral ministry. A number of them juxtapose seemingly contradictory terms in an effort to capture the complex array of internal conflicts and external role expectations that routinely beset ministers. The six chapters that follow portray ministers as personally wounded yet responding to others as healers... In these essays a minister's own feelings of doubt and inadequacy come to the fore but are viewed less debilitating handicaps than as essential tools of the pastoral trade. The wounded healer and wise fool in particular stand alongside images of the living human document and solicitous shepherd as arguably the most enduring and influential metaphors for ministry in contemporary pastoral theology.

(Dykstra 2005:69)

Nouwen's ability to be a wounded healer for others emanated from a spirituality based on his own experiences. In this sense Nouwen's life can be viewed as a 'lived life', and his reflections on pastoral care as 'theology as a way of life' (Veling 2005:236). Nouwen's way of intuitively exploring his own spirituality, as well as the creative way in which he related his personal life to that of others, enabled him to communicate his theological insights in an authentic, empathetic and compassionate way (Gillespie 2002:117). For Nouwen (1975:7), personal experiences are also universal experiences. His personal, subjective and sometimes painful exploration of his inner world opened ways for others to identify with him. The quality and depth of Nouwen's ([1989] 1998:10-12) self exploration are shown in a gripping way in the introduction of his book In the name of Jesus. By sharing his personal struggles with his readers, Nouwen creates safe spaces for people (especially for pastors) to become more aware of their own humanity. Kevin Gillespie (2002) formulates this ability of Nouwen as follows:

It seems that Henri Nouwen wanted us to join his experience of the adventure of life: learning from it, loving through it and laughing about it together. His self-expression of such adventures drew people to him and led him to believe in individual persons being connected in one universal body.

(Gillespie 2002:119)

Nouwen utilises his knowledge and skills as psychologist to explore the value of psychology for pastoral care. Gillespie (2002:121) describes Nouwen's spirituality as a 'post-Vatican II psycho-spirituality. By taking seriously the psychological perspective, [he has] broadened and deepened our understanding of the divine-human encounter.' People's authentic existence (being) in the world is more important to Nouwen than what they do (doing). 
In his diary The road to daybreak: A spiritual journey, Nouwen (1988) states that the existentialist philosopher Martin Heidegger (see Becker 2004:233-255) had a strong influence on his theology. Nouwen makes use of Heidegger's distinction between the concepts of 'Sein' and 'Dasein'. Of these two concepts, 'Dasein' is particularly important for his thoughts on the wounded healer metaphor because Dasein relates to authentic existence in the world. Authentic existence is an existence with the Other (see Collins \& Sellina [1999] 2001:63); in terms of spirituality, God is the Other. In other words, authentic existence means to be with $(\mathrm{O})$ thers $(\mathrm{s})$ - in a relationship with God, self (intrapersonal) and other people (interpersonal). Nouwen uses techniques from the world of psychology to articulate his thoughts on authentic existence. These techniques provide Nouwen with a meaningful vantage point from where human emotions and experiences such as anxiety, isolation, fear and hatred can be interpreted within a broader framework of spirituality (i.e. people's religious experiences). Reflection on religious experiences entails a search for an authentic existence before and with God. Pastoral care is a process by which people are guided in their search for this meaningful existence (Heitink 1993:35). Therefore, spirituality does not mean a withdrawal from reality with the aim of focusing on an individual's inner life alone.

Heitink ([1998] 2000:84-85) shows that there are different currents in relation to the interpretation of spirituality and also expresses his appreciation for the way in which Nouwen developed the correlation between pastoral care and spirituality. Through his emphasis on spirituality, Nouwen brought spirituality into the sphere of theological reflection and in this way added value to the theological discourse on pastoral care. In this respect, Nouwen's thinking correlates with Don Browning's (1991:81) view that in theological circles the commensurability of the philosophical theories underlying scientific methods, as well as the potential value of the humanities and social sciences for the theological discourse are not always considered in a nuanced way. Nouwen, however, succeeds in finding a balance between insights from psychology and theological reflection on pastoral care. This balance finds expression in his discussion on the metaphor of the wounded healer.

\section{THE WOUNDED HEALER}

Nouwen ([1972] 1979) presents his perspective on the wounded healer in his book, The wounded healer: Ministry in contemporary society, by using four narratives. Each narrative is used to show how pastors can, in a compassionate and authentic way, assist people on their life journey. To develop an appreciation for Nouwen's perspective, I shall give a short description of the arguments in his book.

Nouwen ([1972] 1979:3-5) calls his first narrative the 'predicament of nuclear man'. Nouwen uses this epithet to give expression to his conviction that the people of his time have lost their trust in technological progress because they have realised that the creative powers of the human race have the potential to destroy our planet. Nouwen's choice for the phrase 'nuclear generation' probably results from the destructive consequences of nuclear power as it was illustrated by the bombings of Hiroshima and Nagasaki at the end of the Second World War. The nuclear race between the world's super powers in the wake of these bombings has played a significant role in strengthening this distrust of positive progress. This generation can therefore also be called a post-nuclear generation which in itself is almost a cognition of the ability of the human race to destroy itself and the earth. The acknowledgement of this destructive ability gives rise to emotions of anxiety and despondency.

This tendency to cause destruction manifests itself in our current postmodern world in phenomena such as air pollution, depletion of natural resources, inter alia fossil fuels, the endangerment and extinction of large numbers of animal, birds, fish and reptiles, the destruction of rain forests, threat to plant species, and the depletion of the ozone layer with the concomitant increase in earth temperatures. The negative impact of progress and development on the environment has been sustained for centuries by a variety of master narratives, especially the narrative that science will progressively improve people's lives. Although science led to many positive developments, such as combatting illness and poverty, the vast array of negative consequences cannot be denied.

Nouwen ([1972] 1979:8-9) further describes this generation as one without historical continuity, by which he means that those belonging to this generation do not have a connection with meaningful values from their past, and have no hope for the future. A typical feature of this type of society is what Nouwen calls a 'fragmented ideology' (Nouwen [1972] 1979:9-12). Because people are overwhelmed by a wide variety of disparate values, ideas, religious beliefs and lifestyles, they find it difficult to accept one thought system or belief as answer to their dilemmas. The era during which the Christian church could present a solution to humanity's primary predicament (as interpreted and formulated by the church) with a single, comprehensive master narrative, is gone and the church is now continuously challenged by a pluralistic, fragmented society.

David Tracy (1981:ix) encourages faith communities to accept pluralism as part of a new global society as follows: 'The need is to form a new and inevitably complex theological strategy that will avoid privatism by articulating the genuine claims of religion to truth'. Pluralism presents opportunities to faith communities to enrich and broaden their theological traditions and in this way add value to people's lives. Christian faith communities can play a meaningful role in resolving a dualistic tension between church and world by constructively involving themselves in the public domain. Two examples of this kind of public involvement are using resources to partner with institutions and organisations who are involved in sustainable projects for the alleviation of poverty and supporting people who have to live with HIV / Aids. Nouwen succeeds in achieving this by utilising people's struggle to find meaning in their lives as a point of departure for his reflection on the metaphor of the wounded healer.

Nouwen ([1972] 1979:11) also uses the concept 'postmodern' to describe this post nuclear society and generation. A postmodern society is characterised by a greater fluidity and openness of thought than was the case during the modernist era (see Tracy 1981; Lyotard [1979] 1984; Van Aarde 2004:1105-1125). People with a postmodern disposition do not accept the notion of one idea being true and valid for all people at all times. Many people (including many Christian believers) have a critical attitude towards a specific way in which the Christian message is presented, because they experience Christianity as being an ideology tolerating disparate and frequently destructive ideological views. The concept 'postmodern' alludes to changes that gave rise to profound transformations in 'the game rules for science, literature, and the arts' (Lyotard [1979] 1984:xxiii) from the nineteenth century onwards. It was especially during the latter half of the last century that these changes emerged and it was during this era that Nouwen wrote his book on the wounded healer. As Francois Lyotard did, Nouwen perceived the erosion in relation to master narratives, plurality in scientific and cultural discourses, as well as the collapse of traditional power structures and positions (in church and state) and reflected on ways in which pastors could guide a 'nuclear generation' towards an authentic existence in a new world.

According to Nouwen ([1972] 1979:12-15) the generation of his time is also a generation in search of immortality. For many people this search is facilitated outside the framework of the traditional master narrative of the church. Many postmodern Christians do not find comfort or meaning in traditional religious symbols about immortality such as 'heaven', the 'hereafter', the 'second coming of Christ' and the 'kingdom of God'. Because 
people struggle to lead meaningful lives in this world, they do not find comfort in the promise of another, new world. Nouwen ([1972] 1979) formulates this dilemma as follows:

A life after death can only be thought of in terms of a life before it, and nobody can dream of a new earth when there is no old earth to hold any promises.

(Nouwen [1972] 1979:14)

Disillusionment with the world they live in leaves people with two possible ways of creating meaning in their lives, namely mysticism or the way of revolution (Nouwen [1972] 1979:15-18). Nouwen's reduction of people's options to only these two possibilities is an over-simplification, because a plurality of narratives (discourses) can be found in different societies; every individual's life story is unique (see Lyotard [1979] 1984). However, these two poles present a meaningful framework within which Nouwen ([1972] 1979:19-21) suggests a third possibility in terms of which these two extremes can be combined in what Nouwen calls 'The Christian Way'. Nouwen ([1972] 1979) finds this combination personified in Jesus and describes it as follows:

Mysticism and revolution are two aspects of the same attempt to bring about radical change. No mystic can prevent himself from becoming a social critic, since in self-reflection he will discover the roots of a sick society. Similarly, no revolutionary can avoid facing his own human condition, since in the midst of his struggle for a new world he will find that he is also figthing his own reactionary fears and ambitions.

(Nouwen [1972] 1979:19)

Throughout his book Nouwen makes use of this type of dialectical reasoning by which he places two seemingly unreconcilable concepts in juxtaposition to one another. The title of his book, The wounded healer already alludes to this technique. Therefore, Nouwen can state that Jesus is a revolutionary but not an extremist, and a mystic. However, he does not use his intimate relationship with God as an excuse to avoid social justice. I find that at this point Nouwen's thinking converges with that of Tracy (1981:3-46) as far as the public character of theology is concerned. By finding and maintaining a balance between two extreme points of view, Nouwen is successful in keeping his theology relevant for society at large.

\section{FINDINGS}

In his book, Life of the beloved. Spiritual living in a secular world, Nouwen ([1992] 1993) reflects on how, as reported in the Gospel stories in the Bible, Jesus took bread, blessed it, broke it and gave it to his disciples at the last meal (commonly known as the 'last supper') they had shared. Nouwen interprets these acts as symbolising the way in which Jesus was taken by his father, blessed at his baptism, broken on the cross and then given to the world and that the same can be said of people (God's beloved children according to Nouwen). This means that God reveals to people their chosenness and the blessing of being His beloved children; they are broken by life's sorrows and the result of their brokenness is to be given to the world as a gift.

This article reflected on the development of the insight that pastors can view their own brokenness (wounds) as a gift in their lives. It has been shown that the shift from a modern to postmodern paradigm has had an impact on pastors' ministry in the sense that they experience cognitive dissonance because of their being 'trapped' between two mutually exclusive worlds: on the one hand, a global postmodern world in which they and the people they minister have to make a living every day, and on the other, a world characterised by a struggle to live meaningfully and significantly. This struggle manifests itself in their lives and in the lives of others. It has been argued that many ideas that used to be regarded as definite and certain, including religious and Biblical 'truths', have been relativised by the way in which these issues are problematised in a postmodern world, which in turn leads to what is called cognitive dissonance in the life of a pastor. In the postmodern world, pastors' words are no longer viewed as authoritative. In engaging these problems, a number of options are open to pastors, a fundamentalist approach to the Bible and religious truths being one such option.

The article, however, showed that honesty and transparency about their own woundedness and struggles are better options for pastors, because it creates spaces wherein pastors are able to experience their woundedness as a sign of emotional energy and that their emotional pain can, paradoxically, be used as a means towards healing. To facilitate this discussion, the relevance of ancient Greek mythology surrounding the wounded healer and Carl Jung's view thereof has been argued. The short biographical description of Nouwen's life explained why he had a lifelong preoccupation with his own emotional wounds and a struggle to live with them in a meaningful way. The article also showed that pastoral theologians, as well as theologians working in other disciplines, hold Nouwen's work in high regard. In the latter part of the article, the first part of the discussion of Nouwen's exposition of the wounded healer metaphor started to show the relevance of his insights for pastors living in a postmodern world. The follow-up article will further reflect on how Nouwen's exposition of the wounded healer metaphor can be relevant for pastors living in a postmodern world.

\section{REFERENCES}

Becker, R., 2004, 'Der blinde Fleck der Anthropologie: Heideggers "Kehre" als unverfügbare Verfügbarkeit [The blind spot of anthropology: Heidegger's "turn" as uncontrollable availability]', in G. Figal (Hrsg.), Internationales Jahrbuch für Hermeneutik, pp. 233-263, Mohr Siebeck, Tübingen.

Borg, M.J., 2003, The heart of Christianity: Rediscovering a life of faith, Harper, San Fransisco.

Browning, D.S., 1991, A fundamental practical theology, FortressPress, Minneapolis.

Campbell, A.V., [1981] 1986, Rediscovering pastoral care, Darton, Longman \& Todd, London.

Capps, D., 1980, Pastoral counseling and preaching: A quest for an integrated ministry, The Westminster Press, Philadelphia.

Capps, D., 1984, Pastoral care and hermeneutics, Fortress Press, Philadelphia.

Collins, J. \& Selina, H., [1999] 2001, Introducing Heidegger, Icon Books, Cambridge.

Dykstra, R.C., 2005, 'Paradoxical images of care', in R.C. Dykstra (ed.), Images of pastoral care: Classic readings, pp. 69-75, Chalice Press, St. Louis, Missouri.

Edwards, C., 1989, Van Gogh and God. A creative spiritual quest, Loyola Press, Chicago.

Fell, D., [2004] 2005, Van Gogh's women. His love affairs and journey into madness, Robson Books, London.

Frank, A.W., 1995, The wounded storyteller: Body, illness, and ethics, University of Chicago Press, Chicago.

Gillespie, C.K., 2002, 'Similarities and differences: The psychologies and spiritualities of Henri Nouwen and Adrian van Kaam', Theoforum 33(1), 105-121.

Groesbeck, C.J., 1975, 'The archetypal image of the wounded healer', Journal of Analytical Psychology 20, 122-145.

Hadot, P., 2002, What is ancient philosophy?, transl. M. Chase, Belknap Press of Harvard University, Cambridge.

Halliday, M.A.K., 1978, Language as a social semiotic: The social interpretation of language and meaning, Baltimore University Press, Baltimore.

Heitink, G., [1977] 1984, Pastoraat als hulpverlening: Inleiding in de pastorale theologie en psychologie [Pastoral care: Introduction to pastoral theology and psychology], J.H. Kok, Kampen.

Heitink, G., 1993, Praktische theologie: Geschiedenis, theorie, handelingsvelden [Practical theology: history, theory, action domains: manual for practical theology], J.H Kok, Kampen. 
Heitink, G., 1997, 'Ontwikkelingen in de praktische theologie [Develpments in the practical theology]', Praktische Theologie. Nederlands Tijdschrift voor Pastorale Wetenschappen 5, 558-581.

Heitink, G., [1998] 2000, Pastorale zorg: Theologie - differentiatie praktijk [Pastoral care: Theology - differentiation - practice], Uitgeverij Kok, Kampen.

Hiltner, S., [1954] 1958, Preface to pastoral theology, Abingdon Press, New York.

Hodgson, O.C., 1994, Winds of the Spirit: A constructive Christian theology, SCM Press, London.

Jung, C.G., [1929] 1981, 'Fundamental Questions of Psychotherapy', in H. Read, M. Fordham \& G. Adler (eds.), The practice of psychotherapy: Essays on the psychology of the transference and other subjects, Collected Works of C G Jung 16, pp. 111-125, transl. R.F.C. Hull, Princeton University Press, Princeton.

Jung, C.G., [1961] 1963, Memories, dreams, reflections, ed. A. Jaffé, transl. R. \& C. Winston, Pantheon Books, New York.

Jung, C.G., [1954] 1969, 'The psychology of the transference', in H. Read, M. Fordham \& G. Adler (eds.), The practice of psychotherapy: Essays on the psychology of the transference and other subjects, Collected Works of C G Jung 16, pp. 163-320, transl. R.F.C. Hull, Princeton University Press, Princeton.

Lévéque, J.J., 1998, Vincent van Gogh. The path of light, transl. J.S. Kundra, PocheCouleur, Paris.

Liddell, H.G. \& Scott, R., 1974, A lexicon: Abridged from Liddell $\mathcal{E}$ Scott's Greek-English lexicon, Oxford University Press, London.

Louw, D.J., [1999] 2003, Pastoraat as vertolking en ontmoeting: Teologiese ontwerp vir ' $n$ basisteorie, antropologie, metode en terapie [A pastoral hermeneutics of care and encounter], Lux Verbi, Wellington.

Lyotard, J.F., [1979] 1984, The postmodern condition: A report on knowledge, transl. University of Minnesota, Manchester University Press, Manchester.

Malherbe, P.B., \& Louw, D.J., 2002, 'Die dinamika tussen teologiese paradigmas en die verskynsel van uitbranding in die bediening [The dynamics between theological paradigms, and the phenomenon of burnout in the ministry]', Nederduits Gereformeerde Teologiese Tijdskrif 43 (3\&4), 513-522.
Malina, B.J., 2001, The New Testament world: Insights from cultural anthropology, Westminster John Knox Press, Louisville, Kentucky.

Nouwen, H.J.M., [1969] 2000, The living reminder, in Making all things new $\mathcal{E}$ other classics, HarperCollins, London.

Nouwen, H.J.M., [1972] 1979, The wounded healer: Ministry in contemporary society, Doubleday, New York.

Nouwen, H.J.M., 1975, Reaching out: The three movements of the spiritual life, Doubleday, New York.

Nouwen, H.J.M., 1976, The Gennesee Diary: Report from a Trappist monestary, Doubleday, New York.

Nouwen, H.J.M., 1988, The road to daybreak: A spiritual journey, Doubleday, New York.

Nouwen, H.J.M., 1989, 'Foreword', in C. Edwards (ed.), Van Gogh and God. A creative spiritual quest, n.p., Loyola Press, Chicago.

Nouwen, H.J.M., [1989] 1998, In the name of Jesus: Reflections on Christian leadership, The Crossroad Publishing Company, New York.

Nouwen, H.J.M., [1992] 1993, The life of the beloved: Spiritual living in a secular world, Hodder \& Stoughton, London.

Nouwen, H.J.M., [1992] 1994, The return of the prodigal son: A story of homecoming, Darton, Longmann and Todd, London.

O'Laughlin, M., 2005, Henri Nouwen. His life and vision, Orbis Books, New York.

Tracy, D., 1981, The analogical imagination. Christian theology and the culture of pluralism, SCM Press, London.

Van der Ven, J. A., 1998, Education for reflective ministry, Peters Press, Louvain.

Van Aarde, A.G., 2004, 'Postmoderne epistemologie en postkoloniale hermeneutiek [Postmodern epistemology and postcolonial hermeuntics]', HTS Teologiese Studies/ Theological Studies 60(3), 1105-1125.

Veling, T.A., 2005, Practical theology: 'On earth as it is in heaven', Orbis Books, New York. 